\title{
Effect of the Quality of Institutions on Fiscal Pressure in the Countries of the West African Economic and Monetary Union (WAEMU): Evidenced by Informal Sector Channel
}

\author{
Aïcha Tiendrebeogo* Aïchatou Mourfou \\ Department of Economics and Management, University of Ouaga II, Ouagadougou, Burkina Faso
}

\begin{abstract}
This paper aims to analyze the effects of the quality of institutions on the total tax burden through the informal sector in WAEMU countries over the period 1996-2015. The estimation of the parameters by GMPs shows that the improvement in the quality of the institutional environment reduces the size of the informal sector and this reduction in the size of the informal sector in turn leads to an increase in the tax burden rate. It also shows that the level of development and trade openness improve the total tax burden of WAEMU countries, while inflation, the share of agriculture and the informal sector in GDP reduce the total tax burden. As for the share of natural resources in GDP, its effect on fiscal pressure is ambiguous because it varies according to the indicator used to measure the quality of institutions in the regression.
\end{abstract}

Keywords: Tax pressure, Informal sector, Institutions, WAEMU

DOI: $10.7176 / \mathrm{JESD} / 11-20-12$

Publication date:October $31^{\text {st }} 2020$

\section{Introduction}

Financing for development in countries can only be based on external financing. It is necessary to mobilize the country's internal resources for this purpose. These internal resources are essentially based on tax revenues (Romer, 1986; Lucas, 1988; Aghion and Howitt, 1992). It is therefore clear that the mobilization of fiscal resources is imperative for developing countries. Indeed, as Colm and Helzner (1958) the evolution of fiscal structures is linked to evolution of economic growth. Indeed, according to Aghion and Howitt (1992), a good tax policy encourages firms to invest in physical capital and innovation. These investments lead to wealth creation and job creation, which improves economic growth and development. In WAEMU countries, tax revenue mobilization is weak. In fact, over the period 1996 to 2015, the share of tax revenue in GDP was on average 11.94\% annually (World Bank, 2018). This rate is lower than the minimum rate of $20 \%$ suggested in the framework of multilateral surveillance of WAEMU countries. This weakness in tax revenue is also observed in an environment where the quality of institutions is less brilliant (World Government Indicator (WDI), 2018). In addition to these facts, there is a large preponderance of informality in these countries (WAEMU). Indeed, according to a study by the International Monetary Fund (Medina and Schneider, 2018), the size of the informal sector, approximated by the contribution of the informal sector to GDP, was close to 50\%. This size is very large compared to other regions of the world (34\% for Southeast Asia and 23\% for Europe, according to the same study). The low tax revenue mobilization capacity in developing countries reflects the need to seek new reforms tailored to the specific case of these countries. In this respect, Kaldor (1963) suggests that any tax reform must be accompanied by political will, since a country's tax system reflects its political institutions. Furthermore, Chambas (1994; 2005) argues that SubSaharan African countries need a profound reform in organization of tax administrations for a successful tax transition. This weak mobilization is also attributed to the large size of the informal economy in developing countries. Thus, authors such as Ruge (2010); Tafenau et al, (2010), Herwartz et al, (2015), Remeikiene et al, (2014), suggest that large size of informal economy is impediment to tax revenue mobilization. Notwithstanding these facts, it seems that preponderance of informality in developing countries is attributable to the low quality of institutions in these countries. Indeed, according to authors such as Chong and Gradstein (2004), Krakowski (2005), Schneider and Badekow (2006), Schneider (2010); development of country's informal economy is mainly due to the poor quality of public institutions in that country.

It thus appears that firstly, low institutional quality leads to a large size of the informal economy and secondly, low institutional quality hinders the mobilization of tax revenues. This paper based therefore on the theoretical literature, attempts to determine the effect of the informal economy on the tax burden, through the quality of institutions. Specifically, the paper examines whether improving the quality of institutions by reducing the size of the informal economy will improve tax revenue mobilization. In the remainder of the paper, we first present a synthesis of the literature, then the methodology and variables used, and finally the results and their interpretation, followed by a conclusion.

\section{Literature}

In this literature, the authors explain the size of the informal sector by quality of institutions, and show that this 
quality affects tax revenue mobilization through the size of the informal sector.

Theoretically, Friedman et al (2000) show that entrepreneurs do not decide at first sight to operate in informality in order to avoid paying taxes. They make this choice to reduce the burden of bureaucracy and corruption. But this choice will lead to a decrease in tax mobilization later on. Dessy and Pallage (2001) confirm this thinking by developing a theoretical model that offers an endogenous differentiation of the effect of the size of the informal economy on the tax burden between rich and poor countries. Similarly, Alm and Torgler (2004) reveal that the choice to pay taxes depends on the quality of the institutions and differs between countries. They find that a large size of the informal economy is associated with low tax mobilization. But they also find that the size of informality is explained by the quality of institutions. Furthermore, Schneider and Klinglmair (2004) postulate that higher tax rates on the formal sector combined with high regulation induce firms to operate in the informal sector, which necessarily leads to an increase in the informal economy in a country. They also point out that the shift of such enterprises to the informal economy undermines public finances and further weakens the capacity of the State to protect property rights.

Empirically, Alm and Martinez-Vazquez (2007) conduct their study on a sample of developed and developing countries for the year 2000. They find that an improvement in the quality of institutions reduces the size of the informal sector, which allows for a better capacity to mobilize fiscal resources. However, they report that the negative effect of the size of the informal sector on the tax burden diminishes as the level of economic development increases. The latter depends on the quality of the institutions as shown by Acemuglu (2005). Also, Torgler and Schneider (2007), using 25 different proxies for measure governance and institutional quality. They note that good quality institutional factors lead to a small size informal economy. They conduct their study based on three hypotheses. First, an increase in governance and institutional quality reduces ceteris paribus the size of informal economies. Second, the greater the opportunities for direct political participation by citizens, the smaller the margin for growth of the informal economy. Finally, higher tax morale, defined as the intrinsic motivation to pay taxes, reduces the size of the informal economy in a country, other things being equal. In a similar vein, Davoodi and Grigorian (2007) in their study of Armenia, find that countries with low levels of political and social conflict have lower levels of informal activity and high tax mobilization. For these authors, the size of the informal sector depends on tax morale and the cost of tax evasion and tax fraud. On the other hand, Lavallée and Roubaud (2012), using data from an original series of 1-2-3 surveys of urban households in West Africa conducted in seven major WAEMU cities (Abidjan, Bamako, Cotonou, Dakar, Lomé, Niamey and Ouagadougou) from 2001 to 2002 , establish that in West African capitals, informal production units are not greatly affected by corruption attempts by public officials. However, they point out that it is more likely that larger firms and transport sector enterprises are subject to predatory behaviour by state officials. Also, they show that corruption greatly reduces the performance of companies and thus their ability to contribute to countries' tax revenues.

In sum, first, it is accepted in the literature that an increase in the size of the unregistered economy erodes the tax base. Second, an improvement in the quality of institutions positively and directly affects the tax burden. Finally, it is shown that the quality of institutions affects the tax burden through the size of the informal sector. Unfortunately, this literature does not take a position on the indirect effect of the quality of institutions on the tax burden through the informal sector in the particular case of Sub-Saharan African countries. The following empirical analysis attempts to address this issue.

\section{Methodology}

This section presents models, variables of this research, and estimation techniques.

\subsection{The model}

The literature on the determinants of the tax burden uses Lotz and Morss (1967) as a basic model to explain the level of a country's tax burden rate. Indeed, their model has served as a theoretical framework for empirical work (Stotsky and Wolde-Mariam, 1997; Piancastelli, 2001; Bird, Martinez-Vazquez, and Torgler, 2004; Gupta, 2007) with some extensions. Thus, the theoretical function of analysis is defined as follows:

$$
T / Y=f\left(X_{i} \ldots X_{n}\right)
$$

Where $\mathrm{T}$ is total tax revenue, $\mathrm{Y}$ is income, $\mathrm{T} / \mathrm{Y}$ is the total tax burden rate, and $X_{i}(i=1 \ldots n)$ is various explanatory variables. By specifying the theoretical model described above in a panel, the empirical equation to be estimated is as follows:

$$
T T P_{i t}=\alpha_{0}+\alpha_{1} \text { Inst }+\alpha_{2} X_{i t}+\varepsilon_{i t}(2)
$$

With TTP the rate of total tax pressure, Inst an indicator of the quality of institutions, $\mathrm{X}$ is vector of control variables, the variants of $\alpha$ are the vectors of coefficients and, $\varepsilon$ designates the error terms.

\subsection{Study Variables}

The study uses annual data from 1996 to 2015 for the eight (8) WAEMU countries. 


\section{The endogenous variable the rate of total tax pressure is represented by Tax burden rate}

The Tax Burden (Tax) is measured by the tax ratio, which is the ratio of total tax revenue to GDP. This measure is the most widely used in the literature (Stotsky and WoldeMariam, 1997; Ghura, 1998; Bird, Vazquez, and Torgler, 2004; Gupta, 2007; Botlhole, 2010). Fiscal revenues will be measured by the sum of direct taxes, indirect taxes, taxes on foreign trade, and non-fiscal or parafiscal revenues (including social contributions, fines and penalties, etc.). Data on fiscal pressure comes from the African Development Bank (ADB, 2018).

\section{Variables of interest: Quality of Institutions and the size of the Informal Sector}

The quality of institutions (Inst) is measured by the six (6) governance quality indicators of Kaufmann, Kraay and Zoido-Lobaton (KKZ) of the World Bank as well as by the composite index of institutional quality constructed from these 6 indicators. These six indicators are: Freedom of Expression and Accountability (VA), Political Stability (PS), Government Effectiveness (GE), Quality of regulation (QR), Rule of Law (RL) and Corruption Control (CC). These indicators are taken from the database of Worldwide Governance Indicators, (WGI, 2018). The Composite Institutional Quality Index is calculated using the Principal Component Analysis (PCA) method. PCA is a factorial method that consists of reducing the number of variables used to describe a phenomenon, it's noted Inst in this paper.

Measuring the Size of informal Sector (IS) has always been the subject of much debate. In this study, the rate of vulnerable employment is used as a proxy for the size of the informal sector in WAEMU countries. Vulnerable employment includes family workers and own-account workers. This type of employment is generally associated with informality and poor working conditions because people in vulnerable employment are more likely to have informal work arrangements and less likely to have social security coverage and to benefit from social dialogue (Gammarano, 2018). Similarly, De Soto (1989), Wilson, Velis, and Cheeseman (2006), Bramah and King (2006), Brata and Gunadi (2010), Bocquier, Nordman, and Vescovo (2010), Meagher (2010), Charmes (2014), and, Gherbi (2014) link vulnerable jobs to informal sector jobs. It is assumed that an increase in the rate of vulnerable employment indicates a high size of the informal sector. According to the literature, like the agricultural sector, this sector is hardly taxable. Thus, a negative relationship is expected between the rate of vulnerable employment and the rate of tax burden. Data on the size of the informal economy comes from the World Bank's Word Development Indicators database (WDI, 2018).

\section{Control variables}

These variables concern the traditional determinants of the tax burden. And the data come from the World Bank's Word Development Indicators database (WDI, 2018).

Level of development (GDPh) is approximated by the logarithm of GDP per capita. The higher the GDP per capita, the higher the taxable potential and the easier it is to raise taxes (Lotz and Morss, 1970). Thus the expected sign is positive.

Share of agriculture in GDP (Agri) is supposed to have a negative effect on the tax burden. The agricultural sector is difficult to tax because of the predominance of subsistence activities and often dispersed production units (Shin, 1969; Attila, Chambas, and Combes, 2009).

Share of Natural Resources in GDP (NR) can have a positive effect on the rate of fiscal pressure because this sector generates significant revenues (Bahl, 1971; Chelliah, 1971). On the other hand, according to the theory of the "natural resource curse" evoked by Auty (1997), resource-rich countries tend to neglect tax revenue mobilization because of the large rents offered by this sector (Stotsky and Wolde-Mariam, 1997). Thus, the expected sign is ambiguous.

Degree of openness (OP) measures the volume of trade (imports and exports) with the rest of the world relative to GDP. An increase in the degree of openness should be accompanied by an increase in customs revenues and thus an improvement in the country's tax burden, all other things being equal (Lotz and Morss, 1967; Ndiaye and Korsu, 2014).

According to Botlhole (2010), the costs of Inflation (Inf) to tax revenue mobilization can come from three sources. Indeed, the first is the presence of the Olivera-Tanzi effect, that is, the negative effect of inflation on tax revenues in the presence of collection delays. In addition, the exercise of the tax on certain products with specific tax rates will not automatically adjust to inflation. Finally, the reduction of the tax base because households, in order to protect their wealth from the corrosive effects of inflation, can substitute them for goods or services that are probably less taxed at home. A negative sign is expected.

\subsection{Estimation method}

It should be noted that preliminary tests are necessary in order to choose the appropriate estimation technique. In this regard, stationarity and cointegration tests are carried out. These tests help to avoid spurious regressions. For the present study, the test of Maddala and Wu (1999) as well as that of Choi (2002). The results ${ }^{1}$ show that out of a total of fourteen (14) variables, only one variable (inflation) is level stationary and the others are integrated of

\footnotetext{
${ }^{1}$ Appendix 2
} 
order one. Thus, there is a presumption of cointegration, i.e. the existence of a long-term relationship between the variables. To test this relationship, Pedroni's (1999) test is used. The results ${ }^{1}$ indicate that four of Pedroni's seven statistics reject the null hypothesis of non-cointegration between the variables. There is therefore a long term relationship between the variables.

Following the various preliminary tests, the Mean Group (MG) and Pooled Mean Group (PMG) estimators proposed by Pesaran, Shin, and Smith (1999) are given for the estimates ${ }^{2}$. These models allow for the presence of variables that can be integrated of different orders, either I (0) or I (1), or cointegrated (Pesaran and Shin, 1999). The MG estimator imposes no restrictions on either the coefficients or the estimated variances. The DFE estimator assumes that the parameters are identical between individuals. The PMG estimator considers that the model constant, as well as the short-term coefficients and error variances, may differ between individuals. However, the long-term coefficients are constrained to be identical for all units. Given that WAEMU member countries are working towards long-term convergence of the total tax burden rate (which must be greater than or equal to $20 \%$ in 2019 for all member countries), the PMG estimator is then preferable for the purposes of this study (Keho, 2015). This choice is also validated by the Hausman test, as all the probabilities associated with the tests are greater than $5 \%$ for all specifications.

The model to be estimated is as follows:

Referring to Pesaran et al. (1999), i.e. a sample of $\mathrm{N}$ individuals observed over T periods, with $(N, T) \in N^{*} N$; the following ARDL (Autoregressive Distributed-lagged model) is considered:

$\operatorname{Tax}_{i t}=$ 憈 $\operatorname{Tax}_{i, q-}+\sum_{j=1}^{n} \delta_{i j}^{\prime} Z_{i t}^{p}+\mu_{i}+\tau d_{i t}+\varepsilon_{i t}, i=1,2 \ldots, N ; \mathbb{R}=, 2 \ldots, T$

Where $\mathrm{TTP}_{\mathrm{it}}$ is the explained variable, $Z_{i t}^{p}$ is a matrix of explanatory variables, of format $(\mathrm{kX} 1)$; $\mu_{i}$ represents the individual fixed effects (countries); $\beta_{i j}$ are coefficients assigned to the lagged dependent variables $T T P_{i, t-j}$, and $\delta_{i j}^{\prime}$ is a matrix of scalars of format $(1 \mathrm{X} \mathrm{k})$. If the variables are cointegrated, then the error term $\varepsilon_{i t}$ is a stationary process. In this case, the model can be re-specified as an error-correction model in which the short-term dynamics are influenced by the deviation $\theta_{i}=\theta$ from the long-term relationship:

$\Delta \operatorname{Tax}_{i t}=\varphi_{i}\left(\operatorname{Tax}_{i t-1}-\dot{\theta}_{i} x_{i t}-\delta_{1 i} \mathrm{VI}_{i t-1}\right)-\sum_{j=0}^{n} \delta_{i j}^{*} Z_{i t}-\Delta \delta_{1 i} \mathrm{VI}_{i t-1}+\mu_{i}+\tau d_{i t}+\varepsilon_{i t}$

Where $\theta_{i}$ is the vector of long-term coefficients and $\Delta$ the variation operator between two successive times. The adjustment coefficient $\varphi_{i}$ and the long-term coefficients $\theta_{i}$ are the parameters of interest. It is expected that $\varphi_{i}<0$.

\section{Results of estimates and interpretations}

The results of the effect of the quality of institutions and the highlighting of the transmission channel by the size of the informal sector with their interpretations are presented in this section.

\subsection{Descriptive and graphical analyzis of the data}

Table 1 presents descriptive statistics. The average tax burden over the study period is equal to $14.96 \%$, with a minimum value of 7.57 and a maximum value of 23.19 . While that of the informal sector is $78.87 \%$ and varies between a minimum of 44.12 and a maximum of 91.36 . It can be seen that on average over the period of the study, the size of the informal sector is far greater than the tax burden. It also shows that, on average, the variables indicating the quality of institutions are all negative. This indicates that the quality of institutions is very low in the study area for the period under study. The average growth rate of real GDP per capita is $2.71 \%$. On average the contribution of agriculture to GDP is $31.5 \%$; that of natural resources is $9.64 \%$. Trade openness represents on average $62.67 \%$ of GDP. Finally, the inflation rate averaged $4.14 \%$, which is relatively low.

\footnotetext{
${ }^{1}$ Appendix 3

${ }^{2}$ Appendix 5
} 
Table 1 : Descriptive statistics

\begin{tabular}{lllll}
\hline \hline Variables & \multicolumn{4}{c}{ Standard } \\
Average & deviation & Minimum & Maximun \\
\hline Tax & \multicolumn{2}{c}{ Variables of interest } \\
IS & 14.96841 & 3.427483 & 7.578451 & 23.1909 \\
\multicolumn{5}{c}{ Institutional variables } \\
VA & 78.87181 & 14.5294 & 44.121 & 91.361 \\
PS & -0.4096778 & 0.5252139 & -1.506182 & .4259807 \\
GE & -0.401015 & 0.689471 & -2.264047 & 1.04893 \\
RQ & -0.7946544 & 0.3860821 & -1.61314 & .0762425 \\
RL & -0.5425045 & 0.3198519 & -1.261222 & -.047789 \\
CC & -0.6775607 & 0.4374738 & -1.802306 & .0656045 \\
Inst & -0.6760581 & 0.3655398 & -1.538464 & .176479 \\
& $-2.47 \mathrm{e}-09$ & 1.000001 & -2.119982 & 2.255733 \\
GDPh & Controls variables & & \\
AGRI & 2.712512 & 0.2164734 & 2.202111 & 3.184867 \\
NR & 31.50087 & 9.931655 & 11.88239 & 61.41626 \\
OP & 9.643466 & 5.927427 & 2.42534 & 31.59078 \\
INF & 62.67346 & 18.45338 & 30.73252 & 125.0334 \\
\hline \hline
\end{tabular}

Source: Authors

The graph below shows the joint evolution of the size of the informal sector, the tax burden and the quality of institutions over the period of the study. It can be seen that the evolution of the quality of institutions is not stable. In fact, the curve relative to the quality of the institutions evolves in a jagged pattern. Nevertheless, we observe a downward trend. The rate of fiscal pressure is much lower than the size of the informal sector. However, the evolution of these two indicators seems stable over the period, because it does not fluctuate much, unlike the quality of the institutions.

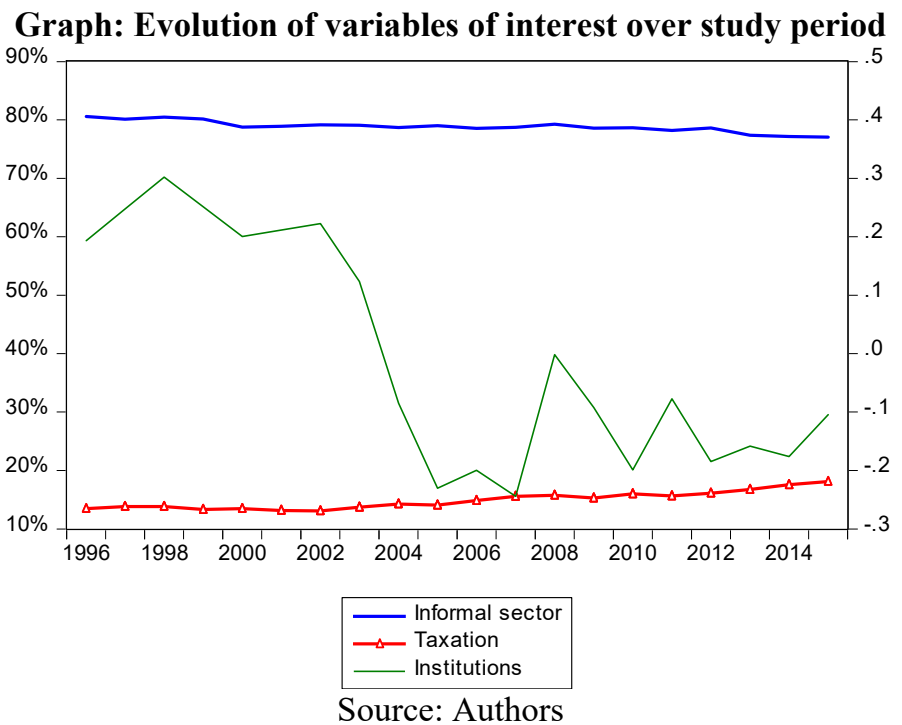

4.2. Effect of the quality of institutions on the tax burden

The main results from the estimates are presented in Table 2. These results show positive and statistically significant coefficients at the 5\% threshold for the various indicators of the quality of KKZ institutions. This means that an improvement in these different institutional aspects promotes better tax revenue mobilization in WAEMU countries. These results corroborate those of Ndiaye (2014). The results are robust because they do not depend on the indicator measuring the quality of institutions. Indeed, the coefficient associated with the composite index is also positive and statistically significant at the 5\% threshold. The poor fiscal performance of WAEMU countries is therefore the result of the poor quality of institutions. For this reason, improving institutional quality is essential for increasing the fiscal pressure in these countries. In fact, an institutional environment characterized by transparency in the management of public affairs, freedom of voting, press and expression, and the possibility of 
denouncing the misconduct of leaders, accompanied by the possibility of losing power through a vote of approval by citizens, improves public confidence in government and therefore provides a considerable incentive for taxpayers to pay taxes. Moreover, a government's ability to formulate sound policies and implement them, and the state's respect with citizens for the institutions governing their economic and social interactions, leads to efficient and effective tax administrations, which facilitates tax collection.

Furthermore, the analysis of marginal effects, presented in Appendix 4 Table 3, reveals that the variables "rule of law", "freedom of expression and accountability" and, "government effectiveness" are the institutional aspects that have a strong influence on the total tax burden rate, compared to other KKZ indicators. Indeed, all other things being equal, it appears that a one-point improvement in "rule of law", "freedom of expression and accountability", and "government effectiveness" is accompanied by an increase in the total tax burden rate by 8.5 , 4 and 2.63 points, respectively. These results imply that WAEMU countries should, primarily, focus on respect for the rule of law, strengthen democratic quality, and improve government efficiency in order to improve tax revenue mobilization capacity. With regard to the control variables, overall, it appears that the level of development and trade openness improve the fiscal pressure in WAEMU countries, while inflation, the share of agriculture and the share of natural resources in GDP reduce the rate of fiscal pressure. These results corroborate those of Attila, Chambas, and Combes (2009) and Keho (2015).

Table 2: Long-Term Results of Estimating the Total Tax Burden Equation

\begin{tabular}{|c|c|c|c|c|c|c|c|}
\hline Variables & (I) & (II) & (III) & (IV) & (V) & (VI) & (VII) \\
\hline VA & $\begin{array}{c}4,0079 * * * \\
(0,000)\end{array}$ & & & & & & \\
\hline SP & & $\begin{array}{c}1,8886 * * * \\
(0,000)\end{array}$ & & & & & \\
\hline EG & & & $\begin{array}{c}2,6327 * * * \\
(0,000)\end{array}$ & & & & \\
\hline QR & & & & $\begin{array}{c}1,8639 * * \\
(0,012)\end{array}$ & & & \\
\hline RL & & & & & $\begin{array}{c}8,5013 * * * \\
(0,000)\end{array}$ & & \\
\hline $\mathrm{CC}$ & & & & & & $\begin{array}{c}2,1874 * * * \\
(0,000)\end{array}$ & \\
\hline Inst & & & & & & & $\begin{array}{c}0,4247 * * * \\
(0,004)\end{array}$ \\
\hline GDPh & $\begin{array}{c}9,2662 * * * \\
(0,000)\end{array}$ & $\begin{array}{c}14,295 * * * \\
(0,000)\end{array}$ & $\begin{array}{l}-0,4477 \\
(0,704)\end{array}$ & $\begin{array}{c}5,3682 * * * \\
(0,000)\end{array}$ & $\begin{array}{c}10,176^{* * * *} \\
(0,000)\end{array}$ & $\begin{array}{c}4,1004 * * * \\
(0,000)\end{array}$ & $\begin{array}{c}6,2215^{* * *} \\
(0,000)\end{array}$ \\
\hline Agri & $\begin{array}{c}0,2717 * * * \\
(0,000)\end{array}$ & $\begin{array}{c}0,2185 * * * \\
(0,004)\end{array}$ & $\begin{array}{c}0,3046 * * * \\
(0,000)\end{array}$ & $\begin{array}{c}-0,0803^{*} \\
(0,063)\end{array}$ & $\begin{array}{c}0,3812 * * * \\
(0,001)\end{array}$ & $\begin{array}{c}0,0851 * * * \\
(0,000)\end{array}$ & $\begin{array}{c}-0,1437 * * * \\
(0,000)\end{array}$ \\
\hline NR & $\begin{array}{c}-0,1318^{* * * *} \\
(0,000)\end{array}$ & $\begin{array}{c}-0,1431 * * * \\
(0,007)\end{array}$ & $\begin{array}{c}-0,0995 * * * \\
(0,004)\end{array}$ & $\begin{array}{c}0,0782 * * \\
(0,038)\end{array}$ & $\begin{array}{c}-0,1307^{*} \\
(0,092)\end{array}$ & $\begin{array}{c}0,0334 * * \\
(0,047)\end{array}$ & $\begin{array}{c}0,0014 \\
(0,967)\end{array}$ \\
\hline OP & $\begin{array}{c}0,1328 * * * \\
(0,000)\end{array}$ & $\begin{array}{c}0,1162 * * * \\
(0,000)\end{array}$ & $\begin{array}{c}0,1437 * * * \\
(0,000)\end{array}$ & $\begin{array}{l}0,0212 \\
(0,200)\end{array}$ & $\begin{array}{c}-.06403 * * * \\
(0.002)\end{array}$ & $\begin{array}{c}0,1019 * * * \\
(0,000)\end{array}$ & $\begin{array}{c}0,0422 * * * \\
(0,000)\end{array}$ \\
\hline Inf & $\begin{array}{c}-0,2139 * * * \\
(0,000)\end{array}$ & $\begin{array}{c}-0,2498 * * * \\
(0,000)\end{array}$ & $\begin{array}{c}-0,1622 * * * \\
(0,000)\end{array}$ & $\begin{array}{c}-0,1071 * * * \\
(0,005)\end{array}$ & $\begin{array}{c}-0,3122 * * * \\
(0,000)\end{array}$ & $\begin{array}{c}-0,1391 * * * \\
(0,000)\end{array}$ & $\begin{array}{c}-0,1249 * * * \\
(0,000)\end{array}$ \\
\hline IS & $\begin{array}{c}-0,4213 * * * \\
(0,000)\end{array}$ & $\begin{array}{c}-0,3009 * * * \\
(0,001)\end{array}$ & $\begin{array}{c}-1,1688 * * * \\
(0,000)\end{array}$ & $\begin{array}{c}-0,1593^{*} \\
(0,087)\end{array}$ & $\begin{array}{c}0,6156^{* * *} \\
(0,000)\end{array}$ & $\begin{array}{c}-0,5905 * * * \\
(0,000)\end{array}$ & $\begin{array}{c}-0,2376^{* * * *} \\
(0,000)\end{array}$ \\
\hline Constante & $\begin{array}{c}4,6794 * * * \\
(0,010)\end{array}$ & $\begin{array}{c}-3,9752 * * * \\
(0,000)\end{array}$ & $\begin{array}{c}45,170 * * * \\
(0,000)\end{array}$ & $\begin{array}{c}8,6276^{* * *} * \\
(0,000)\end{array}$ & $\begin{array}{c}-20,492 * * * \\
(0,000)\end{array}$ & $\begin{array}{c}34,770 * * * \\
(0,000)\end{array}$ & $\begin{array}{c}11,905 * * * \\
(0,006)\end{array}$ \\
\hline Return force & $\begin{array}{c}-\mathbf{0 , 5 6 9 * * *} \\
(0,000)\end{array}$ & $\begin{array}{c}-0,3817 * * * \\
(0,000)\end{array}$ & $\begin{array}{c}-0,5242 * * * \\
(0,000)\end{array}$ & $\begin{array}{c}-\mathbf{0}, 5835 * * * \\
(0,000)\end{array}$ & $\begin{array}{c}-0.3154 * * * \\
(0,000)\end{array}$ & $\begin{array}{c}-\mathbf{0}, 8339 * * * \\
(0,000)\end{array}$ & $\begin{array}{c}-0,6462 * * * \\
(0,003)\end{array}$ \\
\hline
\end{tabular}

Notes : les p-values sont reportées entre les parenthèses. $* * * ; *$ et $*$ indiquent respectivement la significativité à $1 \%, 5 \%$ et $10 \%$. La force de rappel est négative et significative dans toutes les estimations donc le modèle est valide.

\section{Source : Authors}

\subsection{Highlighting the transmission channel: the size of the informal sector}

Theoretically, if the rate of fiscal pressure depends on the share of the informal sector in GDP, which in turn depends on the quality of institutions, the effect of institutional quality on fiscal pressure can be decomposed as follows:

$$
\frac{d t p f}{d w g i}=\frac{\partial t p f}{\partial w g i}+\left(\frac{\partial t p f}{\partial s i} \frac{\partial s i}{\partial w g i}\right)
$$

The aim is to distinguish between the direct and indirect effects of institutional quality, based on the model of Mo (2001), also used by Pellegrini and Gerlagh (2004) and Attila, Chambas, and Combes (2009). In practice, first the direct effect is calculated from equation (2), the results of which are summarized in Table 3 . Then, the effect of the channel of the size of the informal sector (the indirect effect) is evaluated using the results of the estimation of 
equation (2) and those of equation (4). Finally, the total effect is obtained by summing the direct and indirect effect.

$$
s i_{i t}=\beta_{0}+\beta_{1} w g i_{i t}+\vartheta_{i t}
$$

Where if represents the size of the informal sector as a \% of GDP, wgi the composite index of the quality of institutions, the variants of $\beta$ are the vectors of coefficients and, $\vartheta$ denotes the error terms. Estimating this equation by the PMG method gives this result:

$S I=20,8517-1,0337 W G I$

$(0,001) * * *(0,027) * *$

$$
E C=-0,2675
$$

The results in Table 3 give the direct and indirect effects of the quality of institutions on the fiscal pressure within WAEMU countries. It shows that a $1 \%$ improvement in institutional quality directly increases the tax burden rate by $42.47 \%$. It also shows that $24.56 \%$ of this increase in the tax burden is channeled through the informal sector (indirect effect). In other words, improving the quality of the institutional environment by $1 \%$ reduces the size of the informal sector by about $103.37 \%$, and this reduction in the size of the informal sector in turn leads to an increase in the tax burden rate of $24.56 \%$. Consequently, a $1 \%$ improvement in the quality of institutions has a total effect of about $67 \%$ on the tax burden. The contribution of the informal sector to the total effect of the quality of institutions on the tax burden is $36.64 \%$. This means that nearly $36.64 \%$ of the total effect of institutional quality on tax revenue is explained by the size of the informal sector. This implies that the size of the informal sector constitutes a very important channel for transmitting the effect of institutional factors on tax revenue mobilization in the WAEMU zone. For this reason, these countries need to make institutional changes to improve the business climate in order to reduce informal activities in the economy. In this regard, Schneider and Enste (2000) argue that good quality institutions improve the business climate, which encourages firms to operate in the formal sector, thus broadening the tax base. Overall, the results obtained validate the study's hypothesis that the total tax burden of WAEMU economies is largely explained by the quality of institutions, and the size of the informal sector is an important channel for transmitting this effect.

Table 3: Effect of Institutional Quality through the Informal Sector

\begin{tabular}{cccc} 
Effet direct & Canal secteur informel & Effet total & $\begin{array}{c}\text { Contribution relative à l'effet } \\
\text { total }\end{array}$ \\
\hline $\mathbf{0 , 4 2 4 7}$ & $-0,2376^{*}(-1,0337)=\mathbf{0 , 2 4 5 6}$ & $0,4247+0,2456=\mathbf{0 , 6 7 0 3}$ & $0,2456 / 0,6703=\mathbf{0 , 3 6 6 4}$ \\
\hline
\end{tabular}

Source: Authors

\section{Conclusion}

The objective of this research was to analyze the effect of the quality of institutions on the rate of total fiscal pressure through the informal sector in WAEMU countries over the period 1996-2015, using the PMG estimator for econometric investigation. The results show that good quality institutions improve tax revenue mobilization in WAEMU countries. Also, improving the quality of the institutional environment by $1 \%$ reduces the size of the informal sector by about $103.37 \%$, and this reduction in the size of the informal sector in turn leads to an increase in the tax burden rate of $24.56 \%$. Consequently, a $1 \%$ improvement in the quality of institutions has a total effect of about $67 \%$ on the tax burden. The contribution of the informal sector to the total effect of the quality of institutions on the tax burden is $36.64 \%$. In other words, $36.64 \%$ of the total effect of institutional quality on tax revenue is due to the informal sector. Following these results, the paper recommends that WAEMU countries institute effective and efficient institutional reforms that will reduce the size of the informal sector in order to improve tax revenue.

\section{References}

Alm, J., \& Martinez-Vazquez, J. (2007). Tax Morale and Tax Evasion in Latin America. International Studies Program Working Paper 07-32.

Alm, J., \& Torgler, B. (2004). Culture Differences and Tax Morale in the United States and in Europe. Crema working paper No14.

Attila, G., Chambas, G., \& Combes, J.-L. (2009). Corruption et mobilisation des recettes publiques: une analyse économétrique. Recherches Economiques de Louvain, Louvain Economic Review 75(2), 229-268.

Auriol, E., \& Warlters, M. (2004). Taxation Base in Developing Countries. ARQADE and IDEI Toulouse, Place Anatole-France, 31042 Toulouse CEDEX, France.

Backiny-Yetna, P. (2009). Secteur informel, fiscalité et équité : l'exemple du Cameroun. The African Statistical Journal, Volume 9, November 2009, 315-376.

Banque africaine de développement. (2018). Perspectives économiques en Afrique de l'Ouest 2018. ISBN 9789938-882-55-1. 
Biles, J. J. (2009). Informal Work in Latin America: Competing Perspectives and Recent Debates. Geography Compass.

Bird, R. M. (2004). Administrative Dimensions of Tax Reform. Asia-Pacific tax bulletin, 134-150.

Bocquier, P., Nordman, C., \& Vescovo, A. (2010). Employment vulnerability and earnings in urban West Africa. World Development Vol. 38, No. 9, 1297-1314.

Braimah, I., \& King, R. (2006). Reducing the vulnerability of the youth in terms of employment in Ghana through the ICT sector. International Journal of Education and Development using Information and Communication Technology (IJEDICT), Vol. 2, Issue 3, 23-32.

Brata, \& Gunadi, A. (2010). Vulnerability of urban informal sector : street vendors in yogyakarta, indonesia. Theoretical and Empirical Researches in Urban Management Number 5(14) , 47-58.

Breman, J. (1976). A Dualistic Labour System? A Critique of the 'Informal Sector' Concept: I: The Informal Sector. Economic and Political Weekly, Vol. 11, No. 48, 1870-1876.

Chambas, G. (1994). Fiscalité et développement en Afrique subsaharienne. Paris: Economica.

Chambas, G. (2005, Janvier). Afrique au Sud du Sahara : quelle stratégie de transition fiscale? CERDI, Etudes et Documents.

Charmes, J. (2014). Les origines du concept de secteur informel et la récente définition de l'emploi informel. https://www.researchgate.net/publication/255633920.

Chen, M. A., Carr, M., \& Vanek, J. (2004). Mainstreaming informal employment and gender in poverty reduction: a handbook for policymakers and other stakeholders. London: Commonwealth Secretariat.

Davoodi, H. R., \& Grigorian, D. A. (2007). Tax Potential vs. Tax Effort:A Cross-Country Analysis of Armenia's Stubbornly Low Tax Collection. IMF Working Paper 106.

De Soto, H. (1989). The Other Path: The Invisible Revolution in the Third World . Harpercollins.

Dessy, S., \& Pallage, S. (2001). Taxes, Inequality and the Size of the Informal Sector. Université Laval et Université du Québec à Montréal.

Dickens, W., \& Lang, K. (1985). A Test of the Dual labor Market Theory. American Economic Review, Vol. 75 , No. 4 , pp.792-805.

Fauvelle-Aymar, C. (1999). The Political and Tax Capacity of Government in Developing Countries. Kyklos. Vol. $52,391-413$

Fields, G. S. (1975). "Rural-Urban Migration, Urban Unemployment and Underemployment, and job search activity in LDCs. Journal of Development Economics, Vol. 2, pp. 165-187.

Freije, S. (2001). Informal Employment in Latin America and the Caribbean : Causes, Consequences and Policy Recommendations. Instituto de Estudios Superiores de Administración (IESA), Venezuela.

Friedman, E., Johnson, S., Kaufmann, D., \& Zoido-Lobaton, P. (2000). Dodging the grabbing hand: the determinants of unofficial activity in 69 countries. Journal of Public Economics 76, 459-493.

Gammarano, R. (2018). Paid employment vs vulnerable employment: A brief study of employment patterns by status in employment. ILOSTAT, spotlight of work statistic no 3.

Gerry, C. (1987). Developing Economies and the Informal Sector in Historical Perspective. Annals of the American Academy of Political and Social Science, Vol. 493, The Informal Economy, 100-119.

Gherbi, H. (2014). Caractéristiques et déterminants de l'emploi informel caractéristiques et déterminants de l'emploi informel féminin en Algérie. Le cas de la wilaya de Bejaia. Mondes en développement Vol.42 $n^{\circ} 166$, 45-58.

Gong, X., \& Van Soest, A. (2001). Wage Differentials and Mobility in the Urban Labor Market: A Panel Data Analysis for Mexico. Institute for the Studyof Labor Discussion Paper no. 329.

Heckman, J., \& Sedlacek, G. (1985). Heterogeneity, Aggregation and Market Wage Functions: An Empirical Model of Self-Selection in the Labor Market. Journal of Political Econom n 93, pp 1077-1125.

Hosier, R. H. (1987). The Informal Sector in Kenya: Spatial Variation and Development Alternatives. The Journal of Developing Areas, Vol. 21, No. 4, 383-402.

Houngbonon, G. V., Gandzion, O., Ananou, F., \& Houenou, B. (2017). Mobilisation des recettes fiscales dans I'UEMOA: L'UEMOAL'obstacle de l'informel, le levier du mobile-money. L'Afrique des Idées.

Huang, P. C. (2009). China's Neglected Informal Economy: Reality and Theory. Modern China, Vol. 35, No. 4, Whither Chinese Reforms? Dialogues among Western and Chinese Scholars, II, 405-438.

Joubert, N. (2016). Méthodes et travaux d'évaluation statistique de l'économie non-déclarée. Conseil national de l'information statistique.

Keho, Y. (2015). Institutions, Economic Structure and Tax Revenue in UEMOA Countries: A Pool Mean Group Analysis. Journal of Empirical Economics Vol. 4, No. 4, pp. 216-230.

Kucera, D., \& Roncolato, L. (2008). Informal employment: Two contested policy issues. International Labour Review, Vol. 147 , No. 4, 321-348.

Lavallée, E., \& Roubaud, F. (2012). La corruption influence-t-elle les performances économiques du secteur informel en Afrique de l'Ouest? L'économie informelle dans les pays en développement (pp. 145-163). Paris: 
Ferrari /Corporate - Tél . : 0142960550 - J. Rouy / Coquelicot.

Maldonado, C., Badiane, C., \& Miélot, A.-L. (2004). Méthodes et instruments d'appui au secteur informel en Afrique Francophone. SEED Document de travail no 24, Organisation Internationale du Travail, Genève.

Maloney, W. F. (2004). Informality Revisited. The World Bank, Washington, DC, USA.

Meagher, K. (2010). The empowerment trap: gender, poverty and the informal economy in sub-Saharan. $M 2178$ CHANT TEXT.indd, 472-477.

Mo, P. H. (2001). Corruption and economic growth. Journal of Comparative Economics 29, 66-79.

Ndikumana, L. (2001). Fiscal policy, conflict, and reconstruction in Burundi and Rwanda. WIDER Discussion Papers // World Institute for Development Economics (UNU-WIDER), No. 2001/62, UNU-WIDER, Helsinki.

Osoro, N. E. (1995). Tax reforms in Tanzania:Motivations, directions and implications. African Economic Research Consortium Paper 38.

Ossa, R. (2012). Réformes fiscales et développement en Afrique subsaharienne. Saint-Denis: Editions EDILIVRE APARIS Collection Universitaire 93200 .

Ouédraogo, M. F. (2015, Mai). Les déterminants du secteur informel dans les pays en voie de développement : réglementation,corruption, procédures administratives et mode de financement. Mémoire présenté au Département d'économique en vue de l'obtention du grade de maître ès sciences (M.Sc.). Sherbrooke, Québec, Canada: Faculté d'administration, Univerté de Sherbrooke.

Pellegrini, L., \& Gerlagh, R. (2004). Corruption's effect on growth and its transmission channels. KYKLOS, Vol. 57, Fasc. 3, 429-456.

Roubaud, F. (2014). L'économie informelle est-elle un frein au développement et à la croissance économiques ? La Découverte | "Regards croisés sur l'économie » $n^{\circ} 14,109-121$.

Roubaud, F., \& Seruzier, M. (1991). Economie non enregistde par la statistique et secteur informel dans le pays en développement. STATECO no168, INSEE, 130.

Sani, M. (2009). Secteur non enregistré et mobilisation fiscale dans les pays en développement (PED): le cas des pays d'Afrique au sud du Sahara (PASS). Sciences de l'Homme et Société. Université d'Auvergne - ClermontFerrand $I$.

Schneider, F., \& Enste, D. (2000). Shadow Economies: Size, Causes and Consequences. Journal of Economic Literature 38(1), 77-114.

Schneider, F., \& Klinglmair, R. (2004). Shadow Economies around the World: What Do We Know? IZA Discussion Paper No. 1043.

Shome, P. (1999). Taxation in Latin America: Structural trends and impact of administration. IMF Working paper.

Tanzi, V. (1983). The Underground Economy in the United States: Annual Estimates, 1930-80. Staff Papers International Monetary Fund, Vol. 30, No. 2, 283-305.

Teera, J. M. (2003). Could Do Better: An Appraisal of Uganda's Tax Performance Relative to Sub-Saharan Africa.

The World Bank. (2019). Doing business 2019 : Training for reform. A World Bank Group Flagship Report.

Todaro, M. P. (1990). Review. Population and Development Review, Vol. 16, No. 3 , pp. 591-592.

Torgler, B., \& Schneider, F. G. (2007). Shadow economy, tax morale, governance and institutional quality: a panel analysis. CESifo working paper, No. 1923.

Williams, C. C., \& Round, J. (2007). Re-thinking the nature of the informal economy: some lessons from Ukraine. International Journal of Urban and Regional Research 31 (2), pp. 425-441.

Wilson, D., Velis, C., \& Cheeseman, C. (2006). Role of informal sector recycling in waste management in developing countries. Habitat International 30 , 797-808.

Zallé, O. (2017). Essais sur la qualité institutionnelle, la localisation des investissements directs étrangers et la croissance économique en Afrique de l'Ouest. Thèse de Doctorat, Université Ouaga 2, Burkina Faso. 


\section{Appendix 1}

KKZ governance indicators

Freedom of Expression and Accountability (VA): Opportunity for a country's citizens to participate in the appointment of government members. This indicator includes indicators measuring different aspects of the political process, civil liberties, political rights and media independence.

Political Stability (PS): Perceptions of the likelihood that an incumbent government will be destabilized or overthrown by possible unconstitutional and/or violent means, including domestic violence and terrorism.

Government Effectiveness (GE): Perceptions of the quality of public services provided and administration, the competence of civil servants, the independence of the civil service from political pressure, and the credibility of the government's commitment to political leaders.

Quality of regulation (QR): Perceptions of the government's ability to formulate and implement sound policies and regulations that enable and promote private sector development.

Rule of Law (RL): A society's ability to create an environment in which fair and predictable rules provide the basis for economic and social interactions in the protection of property rights. This indicator covers perceptions of the incidence of crime, the effectiveness and predictability of the judiciary, and the ability to enforce and respect contracts.

Corruption Control (CC): Perceptions of corruption defined as the abuse of public power for private gain. It covers both petty corruption, grand corruption, and capture of the state.

Appendix 2

Table 1 : Unit root test results

\begin{tabular}{|c|c|c|c|c|c|c|c|c|c|}
\hline \multirow{3}{*}{ Variables } & \multicolumn{4}{|c|}{ Niveau } & \multicolumn{4}{|c|}{ Différence première } & \multirow{3}{*}{ Conclusion } \\
\hline & \multirow[t]{2}{*}{ MW } & \multicolumn{3}{|c|}{ Choi } & \multirow[t]{2}{*}{ MW } & \multicolumn{3}{|c|}{ Choi } & \\
\hline & & $\mathbf{Z}$ & $\mathbf{L}^{*}$ & Pm & & $\mathbf{Z}$ & $\mathbf{L}^{*}$ & Pm & \\
\hline Tax & $\begin{array}{l}12,8662 \\
(0,6825)\end{array}$ & $\begin{array}{c}1,0160 \\
(0,8452)\end{array}$ & $\begin{array}{c}0,8555 \\
(0,8015)\end{array}$ & $\begin{array}{l}-0,5540 \\
(0,7102)\end{array}$ & $\begin{array}{c}153,2849 * * * \\
(0,0000)\end{array}$ & $\begin{array}{c}-10,423 * * * \\
(0,0000)\end{array}$ & $\begin{array}{c}-15,114 * * * \\
(0,0000)\end{array}$ & $\begin{array}{c}24,269^{* * *} \\
(0,0000)\end{array}$ & I (1) \\
\hline VA & $\begin{array}{l}18,4992 \\
(0,2955)\end{array}$ & $\begin{array}{l}-0,2928 \\
(0,3848)\end{array}$ & $\begin{array}{l}-0,2417 \\
(0,4051)\end{array}$ & $\begin{array}{c}0,4418 \\
(0,3293)\end{array}$ & $\begin{array}{c}90,1746 * * * \\
(0,0000)\end{array}$ & $\begin{array}{c}-7,2746^{* * *} * \\
(0,0000)\end{array}$ & $\begin{array}{c}-8,8508 * * * \\
(0,0000)\end{array}$ & $\begin{array}{c}13,1123^{* * *} * \\
(0,0000)\end{array}$ & I (1) \\
\hline PS & $\begin{array}{l}15,0365 \\
(0,5220)\end{array}$ & $\begin{array}{c}0,2564 \\
(0,6012)\end{array}$ & $\begin{array}{c}0,2042 \\
(0,5804)\end{array}$ & $\begin{array}{l}-0,1703 \\
(0,5676)\end{array}$ & $\begin{array}{c}108,7573 * * * \\
(0,0000)\end{array}$ & $\begin{array}{c}-8,4219 * * * \\
(0,0000)\end{array}$ & $\begin{array}{c}-10,711 * * * \\
(0,0000)\end{array}$ & $\begin{array}{c}16,397 * * * \\
(0,0000)\end{array}$ & I (1) \\
\hline GE & $\begin{array}{c}18,8823 \\
(0,2748)\end{array}$ & $\begin{array}{c}0,7962 \\
(0,7870)\end{array}$ & $\begin{array}{c}0,8146 \\
(0,7902)\end{array}$ & $\begin{array}{c}0,5095 \\
(0,3052)\end{array}$ & $\begin{array}{c}107,0397 * * * \\
(0,0000)\end{array}$ & $\begin{array}{c}-7,5598 * * * \\
(0,0000)\end{array}$ & $\begin{array}{c}-10,414 * * * \\
(0,0000)\end{array}$ & $\begin{array}{c}16,0937 * * * \\
(0,0000)\end{array}$ & I (1) \\
\hline QR & $\begin{array}{l}10,1765 \\
(0,8572)\end{array}$ & $\begin{array}{c}1,5188 \\
(0,9356)\end{array}$ & $\begin{array}{c}1,5680 \\
(0,9380)\end{array}$ & $\begin{array}{l}-1,0295 \\
(0,8484)\end{array}$ & $\begin{array}{c}94,0162 * * * \\
(0,0000)\end{array}$ & $\begin{array}{c}-7,0583 * * * \\
(0,0000)\end{array}$ & $\begin{array}{c}-9,1922 * * * \\
(0,0000)\end{array}$ & $\begin{array}{c}13,7914^{* * * *} \\
(0,0000)\end{array}$ & I (1) \\
\hline RL & $\begin{array}{l}18,1004 \\
(0,3181)\end{array}$ & $\begin{array}{l}-0,3029 \\
(0,3810)\end{array}$ & $\begin{array}{c}-0,3276 \\
(0,3724)\end{array}$ & $\begin{array}{c}0,3713 \\
(0,3552)\end{array}$ & $\begin{array}{c}84,9732 * * * \\
(0,0000)\end{array}$ & $\begin{array}{c}-6,6833 * * * \\
(0,0000)\end{array}$ & $\begin{array}{c}-8,3098 * * * \\
(0,0000)\end{array}$ & $\begin{array}{c}12,1929^{* * *} \\
(0,0000)\end{array}$ & I (1) \\
\hline $\mathrm{CC}$ & $\begin{array}{l}16,2260 \\
(0,4373)\end{array}$ & $\begin{array}{c}0,1938 \\
(0,5768)\end{array}$ & $\begin{array}{c}0,0167 \\
(0,5066)\end{array}$ & $\begin{array}{c}0,0399 \\
(0,4841)\end{array}$ & $\begin{array}{c}95,6074 * * * \\
(0,0000)\end{array}$ & $\begin{array}{c}-7,4048 * * * \\
(0,0000)\end{array}$ & $\begin{array}{c}-9,3654 * * * \\
(0,0000)\end{array}$ & $\begin{array}{c}14,0727 * * * \\
(0,0000)\end{array}$ & I (1) \\
\hline Inst & $\begin{array}{l}18,8822 \\
(0,2748)\end{array}$ & $\begin{array}{c}0,7962 \\
(0,7870)\end{array}$ & $\begin{array}{c}0,8146 \\
(0,7902)\end{array}$ & $\begin{array}{c}0,5095 \\
(0,3052)\end{array}$ & $\begin{array}{c}107,0397 * * * \\
(0,0000)\end{array}$ & $\begin{array}{c}-7,5598 * * * \\
(0,0000)\end{array}$ & $\begin{array}{c}-10,414 * * * \\
(0,0000)\end{array}$ & $\begin{array}{c}16,0937 * * * \\
(0,0000)\end{array}$ & I (1) \\
\hline $\mathrm{GDPh}$ & $\begin{array}{c}2,0973 \\
(1,0000)\end{array}$ & $\begin{array}{c}3,3905 \\
(0,9997)\end{array}$ & $\begin{array}{c}3,2353 \\
(0,9988)\end{array}$ & $\begin{array}{l}-2,4577 \\
(0,9930)\end{array}$ & $\begin{array}{c}68,0861 * * * \\
(0,0000)\end{array}$ & $\begin{array}{c}-6,0134 * * * \\
(0,0000)\end{array}$ & $\begin{array}{c}-6,6665 * * * \\
(0,0000)\end{array}$ & $\begin{array}{c}9,2076^{* * * *} \\
(0,0000)\end{array}$ & I (1) \\
\hline Agri & $\begin{array}{l}21,8504 \\
(0,1481)\end{array}$ & $\begin{array}{l}-1,5714^{*} \\
(0,0580)\end{array}$ & $\begin{array}{l}-1,4761^{*} \\
(0,0735)\end{array}$ & $\begin{array}{c}1,0342 \\
(0,1505)\end{array}$ & $\begin{array}{c}118,9894 * * * \\
(0,0000)\end{array}$ & $\begin{array}{c}-8,708^{* * *} \\
(0,0000)\end{array}$ & $\begin{array}{c}-11.708 * * * \\
(0,0000)\end{array}$ & $\begin{array}{c}18,2061^{* * *} \\
(0,0000)\end{array}$ & I (1) \\
\hline NR & $\begin{array}{l}15,2549 \\
(0,5061)\end{array}$ & $\begin{array}{c}0,2886 \\
(0,6135)\end{array}$ & $\begin{array}{c}0,2312 \\
(0,5909)\end{array}$ & $\begin{array}{l}-0,1317 \\
(0,5524)\end{array}$ & $\begin{array}{c}108,0750 * * * \\
(0,0000)\end{array}$ & $\begin{array}{c}-8,460 * * * \\
(0,0000)\end{array}$ & $\begin{array}{c}-10,647 * * * \\
(0,0000)\end{array}$ & $\begin{array}{c}16,2767^{* * * *} \\
(0,0000)\end{array}$ & I (1) \\
\hline OP & $\begin{array}{l}21,8945 \\
(0,1466)\end{array}$ & $\begin{array}{l}-0,2142 \\
(0,4152)\end{array}$ & $\begin{array}{l}-0,3944 \\
(0,3476)\end{array}$ & $\begin{array}{c}1,0420 \\
(0,1487)\end{array}$ & $\begin{array}{c}171,6751 * * * \\
(0,0000)\end{array}$ & $\begin{array}{c}-10,631 * * * \\
(0,0000)\end{array}$ & $\begin{array}{c}-16,919 * * * \\
(0,0000)\end{array}$ & $\begin{array}{c}27,5197 * * * \\
(0,0000)\end{array}$ & I (1) \\
\hline Inf & $\begin{array}{c}101,345^{* * * *} \\
(0,0000)\end{array}$ & $\begin{array}{l}-7,97 * * * \\
(0,0000)\end{array}$ & $\begin{array}{l}-9.98 * * * \\
(0,0000)\end{array}$ & $\begin{array}{l}15.08^{* * * *} \\
(0,0000)\end{array}$ & & & & & I (0) \\
\hline IS & $\begin{array}{l}21,2479 \\
(0,1692)\end{array}$ & $\begin{array}{r}-0,0192 \\
(0,4924)\end{array}$ & $\begin{array}{l}-0,1761 \\
(0,4305)\end{array}$ & $\begin{array}{c}0,9277 \\
(0,1768)\end{array}$ & $\begin{array}{c}153,69 * * * \\
(0,0000)\end{array}$ & $\begin{array}{c}-10,11 * * * \\
(0,0000)\end{array}$ & $\begin{array}{c}-15,14^{* * * *} \\
(0,0000)\end{array}$ & $\begin{array}{c}24,34 * * * \\
(0,0000)\end{array}$ & I (1) \\
\hline
\end{tabular}

Notes : Les valeurs entre les parenthèses sont les p-values. $* * *, * *$ et * désignent respectivement la stationnarité aux seuils de $1 \%, 5 \%$ et $10 \%$. I (0) et I (1) désignent respectivement la stationnarité de la variable à niveau et d'ordre 1.

Source : Authors 
Annexe 3

Table 2 : Panel cointegration test results for fiscal pressure

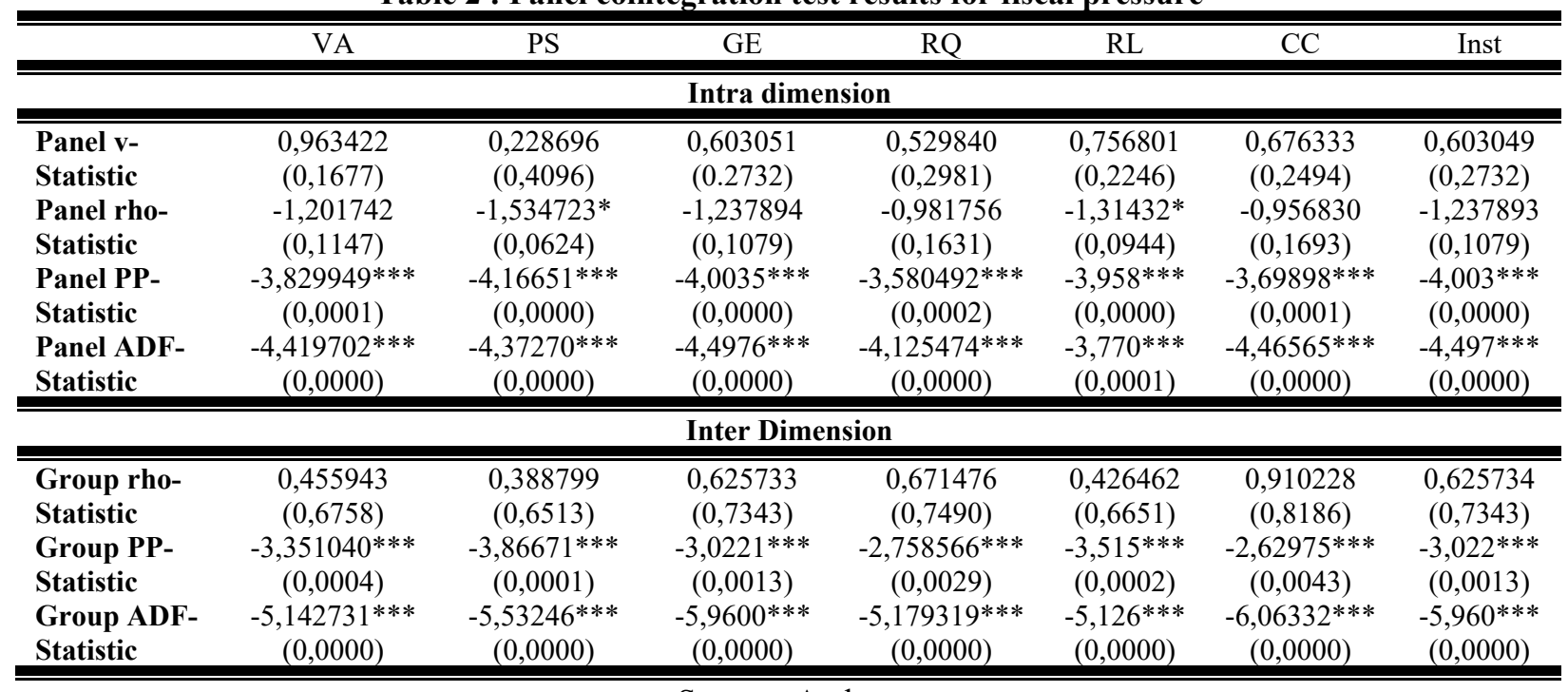

Source : Authors

Annexe 4

Table 3 : Marginal effects

\begin{tabular}{cc}
\hline \hline Variables & Effets marginaux \\
\hline \hline Freedom of Expression and Accountability & $\mathbf{4 , 0 0 7 9 * * *}$ \\
Political Stability & $(\mathbf{0 , 0 0 0 )}$ \\
& $\mathbf{1 , 8 8 8 6 * * *}$ \\
Government Effectiveness $(\mathrm{GE})$ & $\mathbf{( 0 , 0 0 0 )}$ \\
& $\mathbf{2 , 6 3 2 7 * * *}$ \\
Quality of regulation $(\mathrm{QR})$ & $\mathbf{( 0 , 0 0 0 )}$ \\
& $\mathbf{1 , 8 6 3 9 * *}$ \\
Rule of Law $(\mathrm{RL})$ & $\mathbf{( 0 , 0 1 2 )}$ \\
& $\mathbf{8 , 5 0 1 3 * * *}$ \\
Corruption Control $(\mathrm{CC})$ & $\mathbf{( 0 , 0 0 0 )}$ \\
& $\mathbf{2 , 1 8 7 4 * * *}$ \\
\end{tabular}

Source : Authors

Annexe 5

Tableau 4 : Hausman Test

\begin{tabular}{lcc}
\hline \multicolumn{1}{c}{ Variables } & chi2(7) & chi2 Probability \\
\hline \hline Specification 1 & 0,79 & 0,9976 \\
Specification 2 & 0,89 & 0,8342 \\
Specification 3 & 1,02 & 0,9946 \\
Specification 4 & 0,8 & 0,9975 \\
Specification 5 & 0,79 & 0,8751 \\
Specification 6 & 0,81 & 0,7745 \\
Specification 7 & 1,02 & 0,9946 \\
\hline \hline
\end{tabular}

